\title{
WOMEN'S POLITICAL REPRESENTATION IN EUROPEAN COUNTRIES. A COMPARATIVE ANALYSIS AND EXAMPLES OF GOOD PRACTICE
}

\author{
Gabriela MO'TOI ${ }^{1}$
}

DOI: 10.35782/JCPP.2019.2.06

\begin{abstract}
The women's political participation was a long way, which started at the beginning of the XXth century and especially at the end of the First World War. Whatever the country, women began to demand their rights regarding participation in political life and thus the right to vote when they considered that there was a chance they can get it. The reason why women could participate in political life earlier in some countries than in others refer to the fact that in those countries either did not existed or there were no significant tensions between social classes, either feminist movements that fought for this right were quite moderate.
\end{abstract}

Keywords: gender differences; political representation; women; European regulations; seats in Parliaments

\section{Introduction and context}

The subject of this article is of particular sociological importance, given the massive volume of specialized papers dedicated to this problem, which highlight the fact that existing patterns of male/female interaction "must not be based on refusal of women's access to education, social and political institutions and functions, because this fact would indicate a facade democracy" (Kelly and Hanwkesworth, 2004, p.14). Women's 'advocacy' programs have long focused on improving the 'status of women' (Sen, 2000, p. 22), but in our days we may observe an expansion of the objectives towards taking into account their role in economic and social life.

For the theoretical part of this article, we chose to include and, implicitly, present three sociological perspectives to analyse women's participation in political life. First of all, we are talking about the theoretical perspectives that attempt to explain this in terms of

${ }^{1}$ Lecturer, Ph.D., University of Craiova, Faculty of Social Sciences, Romania; e-mail: gabrielamotoi@yahoo.com 
gender differences, specific to societies that have a strong traditionalist character (Comte, 2004). In the twentieth century, these theories, based in particular on differences, appear in scientific papers under the titles of "the theories of gender realignment" or "cultural feminism".

The second category we will address in this article is the perspective of "progressive liberal feminism" (Mill, 2013), a perspective that focused on the struggle to obtain equal political and economic rights in the context of capitalist society, with a special emphasis on special policies to achieve equal opportunities.

The third perspective is the conflictualist perspective, taken from Karl Marx and Max Weber, and developed, among others, by the French sociologist Pierre Bourdieu (2013), whose main purpose is to discover and understand the factors of domination, conflict and the means by which social order is preserved.

The second part of the article contains statistical data (including also data on the percentage of seats held by women in national parliaments or in the European Parliament) regarding women's political participation, during 2005-2015, in France and the United Kingdom.

\section{Sociological literature review (Comte, Mill, Bourdieu)}

From a sociological point of view, the idea that men are different from women in terms of biological differences, and the psychological differences lead them to live in different worlds appears mentioned since 1840 in Auguste Comte's work (Course in Positive Philosophy), where the French sociologist speaks about the two types of existing subordination relationships within the family, one of them being the "gender dominantsubordinate relationship" (Comte, 2004).

The author bases this idea, arguing that between the two sexes there are both physical and moral differences, and "the ability to govern is the most foreign to feminine sex because it implies an overall view, impartiality, independence from passions, what usually involves the reason more than the affectivity" (Otovescu, 2003, p. 55).

In the paper System of Positive Polity, Comte considered that women bear more easily subjection than men, because they are much more dominated by feelings, than by rationality. At the same time, Comte advanced the idea that woman is equipped with a lower-size brain than that of the man, which necessarily leads to the development of a lower form of intelligence, based mainly on affections and less on reason. This idea has raised many criticisms among his contemporaries (an illustrative proof being the wellknown Correspondence between A. Comte and John Stuart Mill), and among other sociologists, in later periods. For example, Gustave Le Bon recognized a woman's inferiority to a man, but he was considering it a kind of "charming weakness" (Le Bon, 1890, p. 451). Emile Durkheim did not deny the validity of feminism, considering women's mental simplicity as a virtue, but in the same time, he was promoting the idea that women "should seek equality in the functions which are part of her nature" (Durkheim, 1896, p. 391). 
The views of Comte and Durkheim highlight the socio-cultural obstacles to women's participation in the political life of nineteenth-century society: a society characterized by severe gender disparities that discourage women from leaving the private sphere and moving towards the public one, considering that the woman's main goal is to give birth and to educate children, which is also their most important function in life.

In the second half of the nineteenth century, in the United Kingdom, liberal feminism began to take shape, in 1851, with the public support by John Stuart Mill and Harriet Taylor Mill, of the first plea on the right to vote of women, the two being inspired by the 1850 National Women's Rights Convention from the United States. In fact, in all his public speeches, in the Correspondence with A. Comte, and in the works that he will later publish, Mill argues that gender balance should be a pre-condition for researching the welfare of any society, not just the English society.

In The Suggestion of Women*, John Stuart Mill (2013) analysed on the struggle for equal political and economic rights, in the context of capitalist society, focusing on special policies to achieve equal opportunities. If we only analyse the title of the work, we could say that Mill is a follower of radical feminism, an orientation that "focuses on the oppression of women, only because they are women, regardless of class or race" (Inglehart and Norris, 2000, p. 93), claiming that the three elements that can explain the causes of subordination are sex, sexuality and gender.

But the thesis that the English sociologist supports in the paper mentioned above is that "if men and women are ontologically similar, men's rights must be extended, in order to include women" (Mill, 2013).

Basically, on the one hand, the whole paper is a critique of the injustice done to women in Victorian times and, on the other hand, a request for immediate reforms in the legal, social and political areas (Grunberg, 2002, p. 91).

In fact, John Stuart Mill published his autobiography in which he argued that he had never looked at women as a minority group but as a category of population that accounted for about half of Britain's population and, therefore, had to know and enjoy social and political emancipation.

In fact, this emancipation is one of the most important elements of the utilitarianism thesis, based on a progressive feminism, developed by Mill: "the improvement of women's conditions in a society contributes to the development of the human being because she transmit these new values and ideas through family education to its children, who live in a balanced family, due to the intellectual equality between man and woman" (Moller Okin, 1979, pp. 197-231).

Another theoretical approach on gender differences is the conflictualist approach, the conflictualist theories (in opposition to the consensual ones), having as main purpose to discover and understand the factors of domination, conflict and the means by which the social order is preserved.

Inspired by Marxist sociology (especially the theory of class conflict) or Weberian sociology (especially the concept of "habitus" encountered at Max Weber in 1913, introduced in sociology by Marcel Mauss and developed by Pierre Bourdieu), the 
conflictualist approach substitutes the functionalist perspective of the horizontal structure regarding the social consensus with the vertical structure, in terms of the struggle for obtaining higher positions in social hierarchy.

Basically, the fundamental idea of these approaches is that men are exercising their domination over women in order to gain power and privileges, generating a kind of symbolic violence (Bourdieu, 2013). This is also the orientation of the French sociologist Pierre Bourdieu, who argues that "what is considered a natural difference between women and men is only the result of gender-based construction from a cultural model with masculine dominance" (Ştefanescu, 2003, p. 66). In its conception, women are predominantly shy, weak (in comparison to male gender), withdrawn and witty because of the model promoted through education. He also considers that "the one who is dominated will always agree with the one who dominates, since the dominate has no tools of knowledge other than those of his dominator who give naturalness to the domination relationship. The dominated participates in his own domination, this being the concrete form of symbolic violence" (Ştefanescu, 2003, pp. 66-67).

Thus, the woman will perceived herself as being inferior to the man, weak, submissive, having the obligation to take care of the household and the children as if these aspects were natural and not induced by a male model that influences the perception of the woman. Basically, till the end of the XIXth century, "women were not able to participate in decision-making either in the society they lived or in their own lives; this was happening in a society in which the gender theories were making a clear distinction between the public sphere - politics and culture and the private sphere - family and household" (Otovescu-Frăsie and Motoi, 2010, p. 12).

In post-industrial societies, things became to change, gender roles have undergone certain transformations due to the opportunities offered to women in education and in the labour market, to the characteristics of the modern family (where the division of labour and the distribution of family roles are no longer similar to traditionalist society), these major transformations having a big influence on the political behaviour of women and men

Thus, in some studies, we find the idea that the policy measures of economic development, the gross domestic product per capita, the increase of women's participation in higher education and their insertion into the labour market positively influence the number of women in national parliaments (Alexander and Welzel, 2007, p. 6). Also, according to other studies, women's access to the labour market has had a major impact on their electoral behaviour, especially regarding their political participation and their access to higher education, which has led them to have more liberal attitudes (Inglehart and Norris, 2000, p. 442).

Together with the globalization process, the gender gap analysis has changed. Thus, many studies have emerged, studies that analyse women's image in the media and how the media form the gender stereotypes (especially in relation to women's participation in political life). According to some authors, "the presence of women in politics can be considered 'suspect' through mass media representations that will focus on looks, clothes or will present women as incapable to deal with parliamentary politics and 
pressure. Thus, the media representations will reinforce the prejudices about the presence of women in politics and their adequacy in this space and also they will deepen the distinction between men and women" (Băluță, 2015, p. 11).

As a matter of fact, women's representations in the media, especially in electoral contexts, were the subject of anti-discrimination reports, which analysed the differences in the average coverage of women candidates compared to male, reports that showed "a situation that is not at all favourable to the presence of women in politics; in other words, by promoting and consequently strengthening the traditional gender roles attributed to men and women, the media have an impact on the results of electoral campaigns and, implicitly, on how the political power is divided and exercised" (Consiliul Național pentru Combaterea Discriminării, 2014, pp. 28-29).

As a way to correct these issues in a European Parliament Report from 2013, it is promoted the idea that "new media (social networks, on-line forums, web pages, etc.) provide an opportunity for policymakers, in order to express their interests, to make their career known and to sympathize with the public so they can fight" (European Parliament, 2013, p. 39).

\section{A comparative analysis: France and the United Kingdom (between 2005 and 2017)}

Countries where feminist movements occurred earlier became countries that have a strong level of inclusion of women in political life, thus so numerous studies have shown that there is a positive link between early feminist movements and women's participation in political life.

In France, the minimum gender quota system is determined by the electoral law, the mandatory parity law at national level, and all electoral lists must include both men and women.

By quota we understand "a minimum percentage of women who are present in a government, electoral list or parliamentary assembly. Therefore, the quota system obliges political institutions to offer women the opportunity to participate in political life and to be elected“" (Dahlerup, 2005).

Also, in France, by the Law of 6 June 2000 on equal access of women and men to electoral and elective offices, the political parties that do not have an equal structure of candidates by sex (50/50) are financially 'punished'. However, a two percentage point difference (51 to 49) is allowed, but if this difference is higher, the parties lose a percentage of funding equal to half the percentage difference between female and male candidates. In 2007, this sanction was increased to $75 \%$ of the difference, with effect from 1 January 2008. The French law of 2000 can be considered an example of good practice if we take into account its positive effects, which we present below, in this article, in the form of several percentage data.

Following municipal elections in March 2001, the percentage of women elected to political positions in city councils has almost doubled - from 25 to $47 \%$ (Norris and Krook, 2011, p. 21). Following the Senate elections in September 2001, 42\% of the 
candidates were women, getting one-third of seats in the French Senate, 102 out of 321 (Sineau, 2004, p. 66). In 2004, women held 37.3\% of regional vice-presidents, compared with only 15.1\% in 1998 (Murray, 2010, p. 412).

The interest in women's representation in French politics increased even more in 2006, with Segolene Royal's 2007 French presidency bid. Being the first female candidate with a real chance to be elected, she received special attention that prompted the issue of gender role in the presidential election to be discussed more and more, with an unprecedented intensity until that time.

Although women were still considered "second sex" in French politics by 2010, they occupied positions in offices where the male presence was lower (e.g. municipal councils), following the 2010 elections, "women constituted $48 \%$ of local representatives at national level, demonstrating that laws and sanctions for disobedience are crucial to the success of legislative quotas" (Hoodfar and Tajali, 2011, p. 122).

In 2013, a new electoral law changed how local councillors are elected (introducing a "mixed ticket", a man/woman) and included cities with more than 1,000 inhabitants in the same election procedure as cities with more 3500 inhabitants. In 2014, an important part of the legislation tightened up the condition that the elected representatives should hold several mandates at the same time, thus increasing the presence of women in their elected offices. During 2013 and 2015, France's local electoral system underwent major changes, so that the changes to the electoral code related to the election of the department councils refer to the fact that the voters in each canton of a department have to choose two members, a man and a woman. As a result of this measure: following the March 2015 department election, half $(2,054)$ of all counsellors $(4,108)$ were women.

Regarding the representation of women from France in European politics, it should be noted that even before the adoption of the Parity Law, women held 40.2\% (35/87) of France's seats in the European Parliament. In 2004, holding 43.6\% of the seats occupied by women, the parliamentary delegation of France in the European Parliament was one of the most feminized.

In 2012, the National Assembly (lower house of the bicameral French Parliament) comprised 155 female parliamentarians, of whom 125 were part of the left-wing parties. These data confirm the theory that we find in many specialized studies that show that "left-wing parties are more willing to recruit women and develop strategies to increase their number in the political field, which allows them to be socially affirmed in politics" (Alexander and Welzel, 2007, p. 10).

Five years later, in the 2017 elections, the positive effects of a balanced gender policy were not delayed. Thus, following the September 2017 elections, of the 577 seats in the National Assembly, 229 were occupied by women, which means a $39.7 \%$ share of women; at the same time, of the 348 seats in the Senate, 112 were occupied by women, which mean a share of $32.2 \%$. Following this elections, France has reached the world ranking of women in national parliaments, on the 16th position, overtaking the United Kingdom, who ranked 39th (Inter-Parliamentary Union, 2019). 
In the United Kingdom, the electoral system is voluntary and is based on lists of candidates aiming at choosing at least $35 \%$ of women.

Following the 2010 parliamentary elections, the situation of women was the following: out of a total of 650 members, 144 were women $(22 \%)$. According to the Centre for Women and Democracy (2015), the distribution of female parliamentarians, by political parties, is as it follows: out of a total of 256 labours members, 82 were women; of 306 conservatives, 49 were female and out of a total of 57 liberal-democrats, 7 were women plus 6 additional women, each from another party (Hoodfar and Tajali, 2011, p. 74).

Although, following the 2010 election campaign, the proportion of female candidates increased considerably compared to 2005 , this was compromised by the fact that even in the fifth round of the general election, the leaders of the three main parties were male. However, this increase is significant compared to 2001 or 2005 and reveals that there are clear differences with regard to the distribution of the "weaker sex" within the three parties

The general elections that took place on the $7^{\text {th }}$ May 2015 led to a significant improvement in the representation of women in the political field, namely in the House of Commons of the UK, with some interesting variations in the political parties, so that 191 women were elected in the House of Commons, reaching $29.4 \%$ in the national Parliament.

Thus, during the period 2013-2015, the Conservative Party reached a record level for the party, with 68 parliamentary women, their number rising from 49 candidates in 2010 to 170 in 2015. The labours had 99 women in Parliament, the percentage of women in this party present in Parliament, in 2015, being 43\%, and of the total number of labour candidates in the election of that year, 212 were women. The LiberalDemocrats have lost all female parliamentarians and the Scottish National Party has managed to increase the number of female parliamentarians from $17 \%$ in 2010 to $36 \%$ in 2015 (Centre for Women and Democracy, 2015, p. 8).

As for the representation of UK women in the European Parliament, their share increased from $23.9 \%$ in 2000 to $25.6 \%$ in 2008 and to $33.3 \%$ in 2013 (Centre for Women and Democracy, 2015, p. 18).

Following the parliamentary elections in 2017, women managed to occupy $32.0 \%$ (208 seats) of the Lower House - House of Commons and 26.4\% (208 seats) of the House of Lords, which means a lower position in world rank than after the previous elections and a much lower ranking than countries such as France, Italy, Austria, Belgium, Denmark and others (Inter-Parliamentary Union, 2019).

\section{Conclusions}

One of the conclusions of this article is that increasing access to educational and occupational resources, increases also women's chances of developing professionally, leading to as many women as possible who can benefit from the opportunity to access positions of power, for example, a function in the political area of activity. 
Although gender equality in the field of political life is well regulated, the statistics show a low visibility of women in politics, which leads to their low interest in politics and vice versa.

The two parts of the article - theoretical and the case study part - highlight the main obstacles that limit women's participation in political life. First of all, it is about sociocultural obstacles: in traditional societies dominated by the conservative spirit, the role of women is limited either to work in the household (implicitly to the education of children), or only to carry out activities in areas of activity considered exclusively feminine.

Secondly, it is about how political parties and electoral systems work in a society: we are talking about the lack of promotion of female candidates or the difficulty of women getting an eligible position on electoral lists.

\section{References}

Alexander, A. \& Welzel, C. (2007), Empowering Women: Four Theories Tested on Four Different Aspects of Gender Equality. Presented at the Annual meeting of Midwest Political Science Association, Chicago: Palmer House Hotel, available at http://www.democracy.uci.edu/files/ docs/conferences/grad/alexander.pdf.

Băluță, O. (2015) Gen, politică și mass-media: reprezentări stereotipizate. Cum tragem linia? Sfera Politicii, XXIII, 1 (183), 105-119.

Bourdieu, P. (2013) Limbaj și putere simbolică, Bucharest, Art.

Centre for Women and Democracy (2015) Sex \& Power. Who Runs Britain?, http://www.cfwd. org.uk/uploads/Sex\%20and\%20Power.pdf.

Comte, A. (2004) Curs de filosofie poritivă, vol. IV, Craiova, Beladi.

Consiliul Național pentru Combaterea Discriminării (2014) Rolul mass-media în combaterea discursului instigator la ură, Bucharest

Dahlerup, D. (2005), Strategies to Enhance Women's Political Representation in Different Electoral Systems. Presented at the Women Shaping Democracy, Manila, Philippines, available at http://www.legislationline.org/documents/id/18881.

Durkheim, E. (1896) Le rôle sociale de la femme. L'Année Sociologique, 3, 391.

European Parliament (2013) Women in decision-making: the role of the new media for increased political participation, Bruxelles, http://www.europarl.europa.eu/RegData/etudes/etudes/ join/2013/493010/IPOL-FEMM_ET(2013)493010_EN.pdf.

Grunberg, L. (2002) R)evoluții in sociologia feministă, Iaşi, Polirom.

Hoodfar, H. \& Tajali, M. (2011) Electoral Politics: Making Quotas Work for Women, London, Women Living Under Muslim Laws, https://www.ndi.org/files/Electoral\%20Politics\%20$\% 20$ Making $\% 20$ Quotas $\% 20$ Work $\% 20$ for $\% 20$ Women $\% 20$ (final)_0.pdf.

Inglehart, R. \& Norris, P. (2000) The Developmental Theory of the Gender Gap: Women's and Men's Voting Behavior in Global Perspective. International Political Science Review, 21, 4, 441-463.

Inter-Parliamentary Union (2019) Women in national parliaments. Situation as of 1st of January 2019, http://archive.ipu.org/wmn-e/arc/classif010119.htm.

Kelly, B. \& Hanwkesworth, Y. (2004) Gen, Globalizare şi Democratizane, Iaşi, Polirom. 
Le Bon, G. (1890) La Psychologie des femmes et les effets de leur éducation actuelle. Revne Scientifique, 46, 449-460.

Mill, J. S. (2013) Supunerea femeilor, Cluj-Napoca, Limes.

Moller Okin, S. (1979) Women in Western Political Thought, Princeton, Princeton University Press.

Murray, R. (2010) Second Among Unequals? A Study of Whether France's "Quota Women" are Up to the Job. Politics \& Gender, 6, 1, 93-118.

Norris, P. \& Krook, M. L. (2011) Gender Equality in Elected Office: A Six-Step Action Plan, OSCE Office for Democratic Institutions and Human Rights (ODIHR).

Otovescu-Frăsie, C. \& Motoi, G. (2010) Egalitatea de şanse şi reprezentarea femeilor în politică la nivel global. Revista de Stiünte Politice, 26, 11-19.

Otovescu, D. (2003) Istoria sociologiei. Note de curs, Craiova, Universitaria.

Sen, A., (2000) La liberté des femmes, atout du développement. Le monde diplomatique, 09/2000, https://www.monde-diplomatique.fr/2000/09/SEN/2389.

Sineau, M. (2004) Parité - Le Conseil de l'Europe et la participation des femmes à la vie politique, Strasbourg, Conseil de l'Europe, https://www.coe.int/t/dgap/democracy/Activities/KeyTexts/03_Summaries_of_all_Publications/Genderware_fr.pdf.

Ştefanescu, D. O. (2003) Dilema de gen a educatiei, Iaşi, Polirom. 